\title{
PENGARUH PERILAKU MENCARI UMPAN BALIK TERHADAP KINERJA DENGAN VARIABEL MODERASI KEADILAN PROSEDURAL
}

\author{
Subrantas Adhy Candra ${ }^{1}$, Devani Laksmi Indiastuti ${ }^{2}$ \\ 1Fakultas Ekonomi dan Bisnis, Universitas Jenderal Soedirman, Indonesia \\ ${ }^{2}$ Fakultas Ekonomi dan Bisnis, Universitas Jenderal Soedirman, Indonesia \\ Email Corresponding Author : azka8008@yahoo.co.id
}

\begin{abstract}
Abstrak
Penelitian ini berusaha untuk mengklarifikasi dan menguji kembali hubungan antara perilaku mencari umpan balik terhadap kinerja dimana hasil empiris menunjukkan inkonsistensi temuan. Beberapa penelitian menunjukkan hubungan positif, beberapa penelitian tidak mendukung dan beberapa penelitian justru menemukan adanya hubungan negatif antara perilaku mencari umpan balik dengan kinerja . Sebagian besar penelitian perilaku mencari umpan balik, hanya mengukur dari frekuensi perilaku umpan balik, tidak membahas metode apa yang paling sesuai digunakan, dan siapa yang paling sesuai menjadi sumber umpan balik. Dalam penelitian ini, perilaku umpan balik diukur dengan frekuensi mencari umpan balik dengan metode inquiry dengan atasan sebagai sumber umpan balik. Penelitian ini juga mencoba memasukkan keadilan prosedural sebagai variabel moderasi. Dengan sampel PNS sejumlah 235 orang yang tersebar di 1 KPU provinsi dan 15 KPU Kab/ Kota untuk mencari data mengenai perilaku mencari umpan balik, kinerja dan keadilan prosedural. Dengan menggunakan analis regresi dan uji interaksi membuktikan bahwa perilaku mencari umpan balik berpengaruh positif terhadap kinerja dan keadilan prosedural memoderasi hubungan diantara keduanya.
\end{abstract}

Kata kunci : perilaku mencari umpan balik, keadilan prosedural dan kinerja

\begin{abstract}
This study seeks to clarify and reexamine the relationship between feedback seeking behavior on performance where empirical results show inconsistencies in findings. Some studies show a positive relationship, some studies do not support and some studies actually find a negative relationship between feedback seeking behavior and performance. Most research on feedback seeking behavior, only measuring the frequency of feedback behavior, does not discuss what method is most appropriate to use, and who is most suitable as a source of feedback. In this study, feedback behavior is measured by the frequency of looking for feedback with the inquiry method with the supervisor as a source of feedback. This study also tries to include procedural justice as a moderating variable. With samples 235 civil servant spread in 1 provincial KPU and 15 District KPU to look for data regarding feedback seeking behavior, performance and procedural justice. By using regression analysts and interaction tests prove that feedback seeking behavior has a positive effect on performance and procedural justice moderates the relationship between the feedback seeking behavior and performance.
\end{abstract}

Keywords : feedback seeking behavior, procedural justice, performance

\section{PENDAHULUAN}

Masalah kinerja merupakan topik utama dalam semua organisasi. Permasalahan ini timbul ketika terjadi gap performance. Perilaku mencari umpan balik dapat membantu seseorang memahami perbedaaan (gap) antara desaire performance dengan actual performance (Ashford et al., 2003). Banyak ilmuwan telah berusaha untuk mengklarifikasi dan menguji hubungan antara perilaku mencari umpan balik terhadap kinerja. Namun, hasil empiris menunjukkan inkonsistensi temuan. Beberapa penelitian menunjukkan bahwa umpan balik pada umumnya mengarah pada kinerja positif (Kim et al., 2009; Stobbelier, 2011; Whittaker, 2012). Informasi dari hasil umpan balik membantu karyawan untuk bekerja secara efektif dan menentukan apakah pekerjaan mereka telah memenuhi standar kinerja dan perilaku yang dianggap tepat serta mempelajari bagaimana menjalankan perannya secara efektif ( Witthaker et al, 2012). 
Namun, beberapa penelitian tidak mendukung hubungan positif antara perilaku mencari umpan balik dan kinerja (Ang et al., 1993; Ashford \& Black, 1996). Hal ini terjadi ketika umpan balik yang diperoleh tidak semuanya sesuai atau berguna untuk menyelesaikan pekerjaan yang sedang ditangani. Padahal umpan balik dapat berdampak positif terhadap kinerja apabila umpan balik tersebut diterima, dipahami dan mengarah pada perbaikan kinerja sehingga dapat memotivasi penerima umpan balik ( Jawahar ,2010)

Beberapa penelitian justru menemukan adanya hubungan negatif antara perilaku mencari umpan balik dengan kinerja (Brown et al., 2001; Fedor et al., 1992). Hal ini terjadi ketika nilai perilaku mencari umpan balik sebagian besar didasarkan pada metode monitoring, mengingat dalam metode monitoring, ada kemungkinan pengambilan kesimpulan yang salah mengenai makna dan pentingnya informasi yang diperoleh oleh pencari umpan balik.

Ansel et al ( 2015) dalam meta analisisnya juga menemukan bahwa perilaku mencari umpan balik tidak secara signifikan memberikan pengaruh positif terhadap kinerja. Dari temuan tersebut, dapat diartikan hubungan antara perilaku mencari umpan balik dengan hasil kinerja masih tidak konsisten.

Sebagian besar penelitian perilaku mencari umpan balik, hanya mengukur dari frekuensi perilaku umpan balik, tidak membahas metode apa yang paling sesuai digunakan, dan siapa yang paling sesuai menjadi sumber umpan balik. Bukti empiris dan teoritis telah mendukung bahwa mencari umpan balik dengan metode inqury lebih baik dibanding dengan metode monitoring dalam meningkatkan kinerja ( Northcraft \& Ashford, 1990). Individu dengan kondisi meminta informasi ( inquiry) menyelesaikan tugas dengan lebih cepat dan akurat dibandingkan dengan individu dengan kondisi diberikan informasi secara otomatis. Dalam kondisi meminta informasi , individu memperoleh informasi sesuai dengan kebutuhannya dan dapat menentukan kapan waktu yang tepat atau diperlukan untuk mencari sebuah umpan balik.

Sumber umpan balik dapat dihubungkan dengan kegunaan dari umpan balik tersebut. Ilgen, et al ( 1979) membuktikan bahwa sumber umpan balik sebagai faktor penting yang menentukan penerima untuk menerima dan menggunakan umpan balik tersebut. Studi yang dilakukan Morrison (1993) mengungkapkan bahwa supervisor adalah sumber informasi teknis dan umpan balik kinerja yang lebih baik daripada rekan kerja. Mengabaikan dua faktor tesebut dapat membiaskan hasil dari temuan.

Hampir semua penelitian perilaku mencari umpan balik diukur menggunakan selfassessment ( menilai diri sendiri). Selain itu, kinerja sebagai hasil dari perilaku mencari umpan balik pada beberapa penelitian juga diukur menggunakan self- assessment. Podsakoff et al ( 2003) mengatakan bahwa ketika seseorang diminta untuk menilai sendiri cenderung akan menilai sedemikian rupa untuk mencerminkan sikap, perilaku, atau persepsi yang diinginkan secara sosial (social desirability biases).

Penelitian di bidang keadilan prosedural telah menunjukkan bahwa keadilan prosedural merupakan penentu penting dari sikap dan perilaku. Bukti empiris telah menunjukkan bahwa keadilan prosedural menghasilkan outcome positif (Folger \& Konovsky, 1989). Chorry (2009) dalam penelitiannya menemukan bahwa ketika individu menerima umpan balik atas kinerjanya maka dia akan menilai keadilan terhadap tiga hal yaitu keadilan terhadap umpan balik itu sendiri, keadilan mengenai bagaimana umpan balik itu ditentukan dan keadilan mengenai bagaimana umpan balik tersebut dikomunikasikan kepada mereka.

Keadilan prosedural berkaitan dengan bagaimana organisasi menyediakan umpan balik dan merespon usaha bawahan sehingga mempengaruhi kesan adanya keadilan dalam sebuah keputusan (Sapienza \& Koorsgaard ,1996). Dalam penelitian ini secara khusus, kami menggunakan teori keadilan prosedural untuk berfokus pada bagaimana bawahan melihat 
kesempatan mendapatkan umpan balik yang berkualitas sebagai hasil dari adanya keadilan prosedural. Semakin tinggi keadilan prosedural memberikan persepsi semakin tinggi kualitas umpan balik yang diberikan. Proses umpan balik dianggap adil jika mengandalkan informasi yang akurat, bebas dari bias dan didasarkan pada prosedur yang memadai ( Sparr \& Sonnentag, 2008). Persepsi ini mendorong bawahan untuk berperilaku mencari umpan balik dan berkomitmen melaksanakan hasil umpan balik tersebut dalam rangka memperjelas perannya yang pada akhirnya dapat meningkatkan kinerjanya.

Berdasarkan argumentasi diatas, maka dalam penelitian ini, perilaku umpan balik diukur dengan frekuensi mencari umpan balik dengan metode inquiry dengan atasan sebagai sumber umpan balik. Selain itu untuk menghindari bias, dalam pengukuran perilaku umpan balik selain bersumber dari bawahan juga meminta jawaban atasan untuk mengkonfirmasi jawaban bawahan tersebut. Sedangkan untuk kinerja bawahan dilakukan oleh atasan. Hal ini didasarkan pengalaman atasan sebagai sumber dari perilaku mencari umpan balik dan sebagai pihak yang melakukan penilaian terhadap kinerja bawahan. Pemoderasian keadilan prosedural diharapkan menjadi jawaban atas kelemahan penelitian sebelumnya dimana hasil pencarian umpan balik tidak semuanya sesuai dan bermanfaat terhadap pekerjaan yang ditangani karena faktor bias informasi dan kesalahan pengambilan kesimpulan.

\section{TINJUAN PUSTAKA DAN PERUMUSAN HIPOTESIS}

\section{TINJUAN PUSTAKA}

\section{Perilaku Mencari Umpan Balik}

Ashford dan Cummings (1983) mendefinisikan perilaku mencari umpan balik sebagai sebuah pencarian proaktif yang dilakukan individu untuk mendapatkan informasi evaluatif secara informal. Berbeda dengan umpan balik yang bersifat formal, seperti penilaian kinerja, perilaku mencari umpan balik merupakan pencarian umpan balik yang bersifat informal yang dilakukan hari demi hari (setiap saat dan berkelanjutan).

Perilaku mencari umpan balik merupakan sebuah proses yang terdiri dari tiga tahap yaitu proses motivasi, kognisi, dan perilaku. Tahap motivasi, yaitu tahap individu membangun keinginan atau hasrat untuk mencari umpan balik. Sebagai contoh, seseorang mungkin kurang yakin bahwa hasil pekerjaannya sudah sesuai yang diharapkan atau metode yang digunakan sudah benar sehingga kondisi tersebut menimbulkan keinginan untuk mencari umpan balik. Tahap kognisi . yaitu tahap dimana individu menimbang antara besarnya manfaat yang diperoleh dibandingkan biaya mencari umpan balik. Biaya terkait manajemen kesan misalnya, mencerminkan bagaimana kesan negatif yang akan didapat seseorang dalam mencari umpan balik. Biaya inferensi mencerminkan umpan balik yang diterima tidak seperti yang diharapkan. Tahap perilaku yaitu tahap ndividu memutuskan perilaku mencari umpan baliknya setelah menimbang biaya dan manfaat dari mencari umpan balik.

Bukti empiris menunjukkan bahwa organisasi yang menggunakan umpan balik secara efektif ,memiliki keunggulan kompetitif dalam iklim ekonomi dengan persaingan tinggi (Chatman \& Cha, 2003). Umpan balik merupakan elemen penting dalam organisasi karena mengikat tujuan organisasi dengan kontinuitas dan fluiditas, meningkatkan kreativitas, mendorong kepercayaan, dan mendorong motivasi pada individu (Mulder, 2013). Umpan balik harus sejalan dengan kinerja, tujuan dan misi organisasi secara keseluruhan (Sharma \& Marandure, 2011). Oleh karena itu praktek umpan balik baik secara formal dan informal diperlukan di semua tingkat organisasi. 


\section{Keadilan Prosedural}

Colquitt (2001) mendefinisikan keadilan prosedural berkaitan dengan keadilan prosedur yang digunakan untuk pengambilan keputusan dan dipengaruhi oleh penerapan kriteria proses yang adil seperti ketepatan atau konsistensi. Prosedur dapat dianggap adil oleh karyawan apabila memenuhi kriteria konsistensi, minimalisasi bias, informasi yang akurat, bersifat memperbaiki, representatif/keterwakilan, mengedepankan etika dan bersifat etis. Prosedur yang adil harus konsisten baik dari orang satu kepada orang yang lain maupun dari waktu ke waktu. Dalam upaya minimalisasi bias, baik kepentingan individu maupun pemihakan harus dihindarkan. Pengambilan keputusan bersifat netral, tidak ada unsur kepentingan pribadi. Informasi yang dibutuhkan untuk menentukan agar penilaian keadilan akurat adalah harus mendasarkan pada fakta. Kalau opini sebagai dasar, hal itu harus disampaikan oleh orang yang benar-benar mengetahui permasalahan, dan informasi yang disampaikan harus lengkap. Informasi dan pendapat harus dikumpulkan dan diproses dengan kesalahan seminim mungkin. Upaya untuk memperbaiki kesalahan merupakan salah satu tujuan penting perlu ditegakkan keadilan. Oleh karena itu, prosedur yang adil juga mengandung aturan yang bertujuan mempertimbangkan prosedur-prosedur yang ada untuk memperbaiki kesalahan yang ada ataupun kesalahan yang mungkin akan muncul. Prosedur dikatakan adil jika sejak awal ada upaya untuk melibatkan semua pihak yang bersangkutan. Meskipun keterlibatan yang dimaksudkan dapat disesuaikan dengan sub-sub kelompok yang ada, secara prinsip harus ada penyertaan dari berbagai pihak sehingga akses untuk melakukan kontrol juga terbuka. Prosedur yang adil harus berdasarkan pada standar etika dan moral. Dengan demikian, meskipun berbagai hal tersebut dipenuhi, bila substansinya tidak memenuhi standar etika dan moral, tidak bisa dikatakan adil. Prosedur yang telah diterapkan perusahaan harus memiliki aturan, sehingga prosedur tersebut dapat diterapkan dan dianggap adil oleh seluruh karyawan. Hal tersebut dikarenakan keadilan yang diperoleh karyawan merupakan hasil persepsi dari karyawan terhadap perilaku yang ditunjukkan oleh atasan maupun manajer.

Model keadilan prosedural menjelaskan bahwa keadilan prosedural memberikan persepsi untuk kepentingan diri sendiri dan dengan kelompoknya. Model kepentingan pribadi (self interest) berbasis pada asumsi, bahwa orang berupaya memaksimalkan keuntungan pribadinya ketika berinteraksi dengan pihak lain dan mengevaluasi prosedur dengan mempertimbangkan kemampuannya untuk menghasilkan outcomes yang diinginkannya. Penilaian seseorang mengenai keadilan tidak hanya dipengaruhi oleh outcomes apa yang mereka terima sebagai akibat keputusan tertentu atau keadilan distributif, namun juga pada proses atau bagaimana keputusan tersebut dibuat. Model nilai kelompok menganggap bahwa individu tidak dapat lepas dari kelompoknya. Konsekuensi bagi individu tersebut adalah lebih mengutamakan kebersamaan kelompok daripada kepentingan pribadi. Pada model nilai kelompok memiliki arti bahwa keadilan yang dirasakan karyawan adalah mereka saling membutuhkan dan bekerja sama dalam menjalankan tugas-tugasnya.

\section{Kinerja}

Griffin et al (2007) mendefinisikan performance sebagai keseluruhan tanggung jawab kinerja yang terkait dengan pekerjaan seseorang . Teori peran merupakan pendekatan penting untuk konsep kinerja ini sebagai upaya untuk menggambarkan keseluruhan tanggung jawab kerja dalam sebuah peran seorang karyawan mencakup seluruh perilaku kerja individu dalam konteks organisasi. Selanjutnya Griffin menjelaskan dimensi dari performance terdiri dari kecakapan individu dalam tugas, adaptivitas individu terhadap tugas dan keproaktifan individu dalam tugas. Kecakapan Individu dalam Tugas ( Individual Task Proficiency) mencerminkan tingkat di mana seorang 
karyawan memenuhi persyaratan dan harapan yang diketahui dari perannya sebagai individu. Pada intinya, kecakapan individu terkait erat dengan konsep kinerja tugas (Borman \& Motowidlo, 1993) dan perilaku peran pekerjaan (Welbourne et al, 1998). Adaptivitas Individu terhadap Tugas (Individual Task Adaptivity) mencerminkan sejauh mana individu mengatasi, merespons, dan mendukung perubahan yang mempengaruhi peran mereka sebagai individu. Keproaktifan Individu dalam Tugas (Individual Task Proactivity) mencerminkan sejauh mana individu terlibat dalam perilaku memulai sendiri, berorientasi pada masa depan untuk mengubah situasi dan peran kerja masing-masing.

\section{PERUMUSAN HIPOTESIS}

\section{Perilaku Mencari Umpan Balik dan Kinerja}

Perilaku mencari umpan balik dapat meningkatkan kinerja terutama karena mengarah pada perolehan informasi teknis, peran, dan evaluatif (Morrison, 1993). Informasi ini membantu karyawan untuk bekerja secara efektif dan untuk menentukan apakah pekerjaan mereka telah memenuhi standar kinerja dan perilakunya dianggap tepat (Ashford dan Cummings, 1983).

Perilaku mencari umpan balik juga meningkatkan kemampuan orang untuk mengendalikan pekerjaan mereka sendiri (Chen, et al., 2007) dan dapat mengurangi ketidaknyamanan di lingkungan yang tidak pasti dan samar yang memberi mereka kontrol kecil (Daft dan Lengel, 1986). Ashford dan Cummings (1983) juga membahas bagaimana kemampuan seseorang dikembangkan dan dipertahankan melalui perilaku mencari umpan balik . Dengan rasa kontrol yang lebih besar atas pekerjaan mereka sendiri, rasa manfaat yang diperoleh karyawan menguat, yang pada gilirannya akan memberi efek positif pada kinerja mereka (Hakim, et al., 2007). Bukti empiris telah menunjukkan bahwa karyawan memperoleh pandangan yang lebih akurat tentang kemampuan dan kekurangan diri sendiri setelah mencari umpan balik (Ashford dan Tsui, 1991; Chen et al., 2007).

Menurut Zhou (2008) umpan balik sangat kondusif untuk kinerja kreatif, karena umpan balik mengurangi beberapa ketidakpastian yang terkait dengan perubahan sifat pekerjaan dan membantu pemain untuk menetapkan standar yang kreatif. Perilaku mencari umpan balik mungkin sebagai cara baru yang dipertimbangkan untuk mendorong kinerja ke depan dan merangsang ide-ide baru untuk meningkatkan proses yang lebih kreatif. Stobbeleir et.al (2011) menemukan bahwa perilaku mencari umpan balik adalah variabel intervensi yang relevan dalam hubungan antara gaya kognitif karyawan, dukungan organisasi yang dirasakan untuk kreativitas, dan kinerja kreatif. Mulder \& Ellinger ( 2013) membuktikan bahwa umpan balik berkualitas sangat penting dalam mempengaruhi proses pembelajaran dan pengembangan individu dalam konteks pekerjaan mereka.

Semua ini menunjukkan bahwa kinerja karyawan dapat dipengaruhi oleh perilaku mencari umpan balik sebagai hasil dari ketersediaan informasi yang berkaitan dengan kinerja dan rasa kontrol yang lebih besar. Semakin banyak informasi yang dapat dari proses pencarian akan meningkatkan pemahaman individu tentang standar kinerja dan perilaku yang diharapkan oleh organisasi yang pada akhirnya mengurangi kesenjangan kinerja. Dengan demikian kami mengusulkan hipotesis berikut:

H1 : Terdapat pengaruh positif antara perilaku mencari umpan balik terhadap kinerja 


\section{Pemoderasian Keadilan Prosedural (Prosedural Justice)}

Penelitian telah menunjukkan bahwa persepsi keadilan prosedural berpengaruh terhadap sikap dan perilaku karyawan dalam organisasi (Brader dan Tyler , 2005 ; Masterson et al. 2000). Dalam penelitian ini , berfokus pada keadilan prosedural karena bukti empiris telah menunjukkan bahwa keadilan prosedural menghasilkan outcome positif (Folger dan Konovsky, 1989).

Dalam penelitian ini secara khusus, kami menggunakan teori keadilan prosedural untuk berfokus pada bagaimana bawahan melihat kesempatan adanya umpan balik positif sebagai hasil dari keadilan prosedural sehingga intensitas perilaku mencari umpan baliknya dapat mempengaruhi kejelasan peran dan kinerjanya

Berdasarkan Theory of Task Motivation dari Locke , Chorry (2009) dalam penelitiannya menemukan bahwa ketika individu menerima umpan balik atas kinerjanya maka dia akan menilai keadilan dari umpan balik tersebut, bagaimana feedback itu ditentukan dan bagaimana feedback tersebut dikomunikasikan kepada mereka. Umpan balik yang adil dapat lebih diterima dan dilaksanakan dibandingkan umpan balik yang kurang adil secara prosedural . Sehingga dapat disimpulkan perilaku mencari umpan balik dalam rangka akan meningkatkan kinerja tergantung dari persepsi adil tidaknya sebuah umpan balik.

Nae et al., (2015) meneliti efek moderator kualitas umpan balik dalam hubungan antara perilaku mencari umpan balik dengan kinerja. Data dikumpulkan dari 202 pegawai di Korea Selatan. Hasil menunjukkan bahwa perilaku mencari umpan balik karyawan berhubungan positif dengan kinerja, pengaruhnya lebih kuat bagi karyawan yang merasa mendapat umpan balik kualitas tinggi dari atasan. Penelitian ini menemukan bahwa efek moderator dari kualitas umpan balik terhadap hubungan antara perilaku mencari umpan balik dan kinerja lebih kuat ketika karyawan memiliki tingkat kepercayaan yang tinggi terhadap atasan mereka. Kepercayaan terhadap atasan merupakan sebuah outcomes dari keadilan prosedural yang ada dalam organisasi tersebut (Pillai et al. 1999; Jawahar;2007).

Penelitian yang dilakukan oleh Li et al., (2016) pada sebuah hotel di China dengan sampel sebanyak 248 menemukan bahwa partisipasi bawahan dalam membuat keputusan dapat menstimulasi dan mendorong perilaku bawahan dalam mencari umpan balik. Kesempatan partisipasi bawahan selama pengambilan keputusan ada di dalam sebuah organisasi dimana terdapat keadilan prosedural. Berdasarkan uraian diatas dan hasil penelitian sebelumnya maka dirumuskan hipotesis sebagai berikut :

H2 : Keadilan prosedural memoderasi hubungan antara perilaku mencari umpan balik dengan kinerja

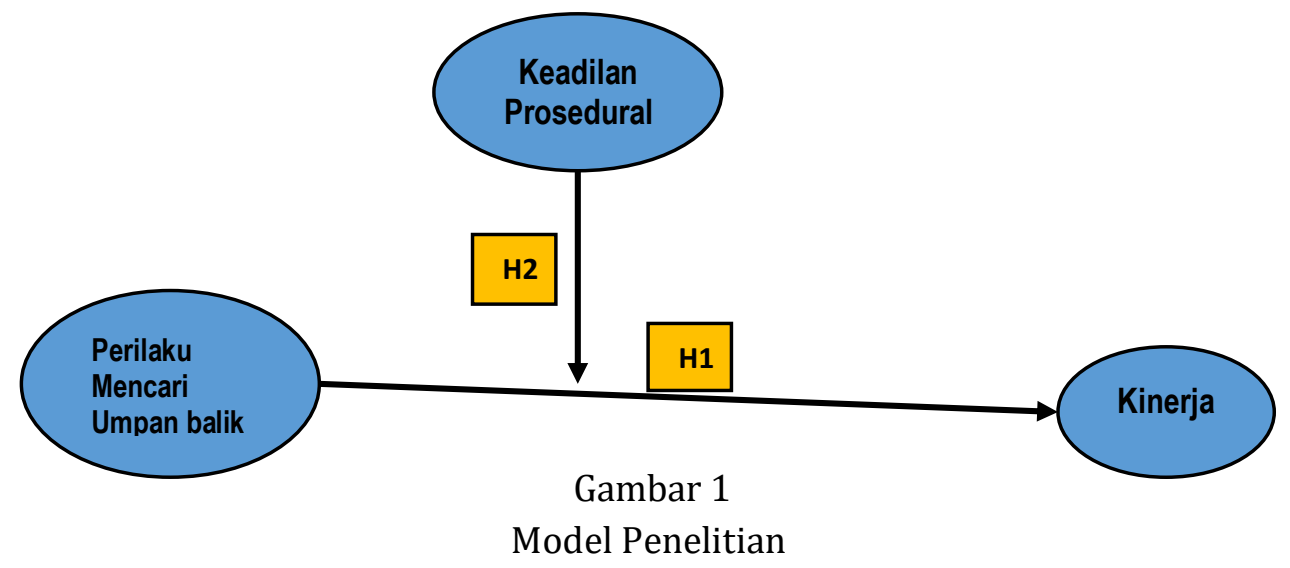




\section{METODOLOGI PENELITIAN}

Jenis penelitian ini merupakan penelitian survey, yaitu dengan memberikan daftar pertanyaan menggunakan kuesioner pada seluruh staf dan kasubag (atasan) yang menjadi sampel dalam penelitian. Motede pengambilan sampel yang digunakan dalam penelitian ini dengan menggunakan non-probability sampling, yaitu teknik sampling yang tidak memberikan peluang yang sama bagi setiap anggota populasi atau unsur untuk menjadi sampel. Salah satu teknik non-probability sampling yang akan digunakan dalam penelitian ini adalah dengan dengan teknik purposive sampling yaitu teknik penentuan sampel dengan kriteria tertentu (Sugiyono, 2012). Kriteria yang dimaksud yaitu kemudahan jangkauan dan komunikasi dalam rangka mendapatkan sampel.

Dari populasi sebesar 415 diambil sampel sebanyak 245 responden. Data dikumpulkan dengan cara menyebarkan kuesioner secara langsung kepada responden yang tersebar di 1 KPU provinsi dan $15 \mathrm{KPU}$ Kab/ Kota di wilayah Jawa Tengah untuk mencari data mengenai perilaku mencari umpan balik, kinerja dan keadilan prosedural. Untuk variabel perilaku mencari umpan dan keadilan prosedural bersumber dari bawahan/ staf. Sedangkan untuk kinerja bawahan diisi oleh atasan langsung yaitu kepala subbagian. Peneliti juga meminta atasan untuk mengisi variabel perilaku mencari umpan balik bawahan sebagai bahan konfirmasi atas jawaban bawahan. Dari 245 buah kuesioner yang disebar semuanya kembali tetapi ada 3 kuesioner tidak lengkap dan 7 kuesioner mempunyai jawaban kontradiktif atau ada jawaban berkebalikan antara responden dengan jawaban konfirmasi dari atasan. Sehingga dalam penelitian ini terdapat 235 (96,92 \%) kuesioner yang akan digunakan dalam perhitungan analisis

Dalam penelitian ini, digunakan skala pengukuran yang sudah ada dari penelitian sebelumnya. Perilaku mencari umpan balik diukur menggunakan skala yang dikembangkan oleh Ashford dan Black (1986) yang terdiri dari 4 item pertanyaan . Keadilan Prosedural menggunakan skala yang dikembangkan oleh Colquitt (2001) yang terdiri dari 7 item pertanyaan dan Kinerja menggunakan skala yang dikembangkan oleh Griffin et.al (2007) yang terdiri dari 7 item pertanyaan.

Dalam menguji hubungan antara perilaku mencari umpan balik terhadap kinerja menggunakan analisis regresi. Pemoderasi keadilan prosedural diuji dengan menggunakan uji interaksi.

\section{HASIL DAN PEMBAHASAN}

Berdasarkan hasil pengujian pada Tabel 1 dapat diketahui bahwa perilaku mencari umpan balik berkorelasi positif terhadap kinerja dengan nilai $\boldsymbol{\beta}=0,504$ dengan signifikansi sebesar 0.00 atau lebih kecil dari level of siginificant 0,05 ( $5 \%$ ). Dilihat dari thitung $(9,967)$ juga lebih besar dari $t$ tabel $(1,651)$. Hal ini menunjukkan pengaruh positif antara bahwa perilaku mencari umpan balik terhadap kinerja secara populasi dikatakan signifikan. Berarti hipotesis 1 ( H1) yang menyatakan bahwa terdapat hubungan positif antara perilaku mencari umpan balik dengan kinerja dapat diterima.

Dari hasil pengujian hipotesis terbukti bahwa perilaku mencari umpan balik berpengaruh positif terhadap kinerja. Peningkatan frekuensi perilaku mencari umpan balik melalui metode inquiry kepada atasan akan meningkatkan kinerja. Hasil dari penelitian ini menguatkan beberapa penelitian yang pernah dilakukan sebelumnya (Ashford et al., 2003; Chen, et al., 2007; Hakim, et al., 2007). 
Tabel 1 . Ringkasan Hasil Regresi

\begin{tabular}{lrcr}
\hline \multirow{2}{*}{\multicolumn{1}{c}{ Variabel Independen }} & \multicolumn{3}{c}{ Variabel Dependen } \\
\cline { 2 - 4 } & \multicolumn{3}{c}{ Performance (Y) } \\
\cline { 2 - 4 } Feedback Seeking Behavior (X) & 0,504 & 9,967 & 0,000 \\
\hline Nilai R & 0,536 & \\
Nilai R ${ }^{2}$ & 0,288 & \\
Nilai Adjusted R ${ }^{2}$ & 0,284 & \\
Nilai t tabel & 1,651 & \\
Nilai $\beta$ (Constant) & 27,171 & \\
N & 235 & \\
\hline
\end{tabular}

Hasil dari perilaku mencari umpan balik adalah informasi/ pendapat dari atasan terhadap tugas atau pekerjaan baik selama proses pengerjaan atau setelah selesainya tugas. Umpan balik atasan pada setiap tahap penyelesaian tugas akan lebih membantu karena ketika ada perbedaan ekspektasi antara atasan dan bawahan, akan lebih cepat mendapatkan koreksi dan segera dilakukan perbaikan. Meningkatnya frekuensi mencari umpan balik akan semakin memperkecil perbedaan ekspektasi antara bawahan dan atasan sehingga bawahan dapat bekerja secara lebih efektif.

Atasan sebagai pimpinan mereka adalah figur yang paling mengetahui apa tujuan dan sasaran organisasi/unit mereka, apa saja pekerjaan yang harus dilakukan untuk mencapai sasaran, apa saja beban pekerjaan yang menjadi tanggungjawabnya dan bagaimana beban dan tanggungjawab tersebut diturunkan kepada bawahan berdasarkan tingkat kemampuan bawahan. Melalui perilaku mencari umpan balik terhadap atasan, bawahan dapat mengetahui informasi tentang tugas dan tanggungjawab dari pekerjaan mereka.. Umpan balik atasan dapat memberikan informasi yang jelas tentang apa peran bawahan , bagamaina menjalankan peran tersebut sesuai prosedur yang benar, berapa lama waktu yang ditentukan untuk menyelesaikan pekerjaan, membuat jadwal dan membagi waktu secara tepat, menentukan prioritas pekerjaan dan hasil pekerjaan seperti apa yang diharapkan oleh atasan sehingga bawahan tidak lagi bekerja dengan metode trial dan error. Penelitian ini mengkonfirmasi penelitian Rizzo et al. (1970) yang menyatakan bahwa dalam kondisi adanya ambiguitas peran, ada kemungkinan bahwa individu akan bergantung pada metode trial and error untuk mencocokkan harapan atasan. Informasi yang diperoleh dari proses mencari umpan balik membantu bawahan dalam rangka memenuhi standar kinerja, prosedur dan perilaku yang dianggap tepat oleh organisasi melalui atasan mereka.

Hasil dari analisis regresi variabel moderasi keadilan prosedural dalam hubungan antara perilaku mencari umpan balik terhadap kinerja dengan menggunakan metode uji interaksi dapat dilihat dalam Tabel 2. Berdasarkan output dapat diketahui bahwa yaitu hubungan keadilan prosedural dengan kinerja (b2) signifikan $(\beta=0,290$; Sig=0,000 < alpha $0,05)$ dan diketahui hubungan variabel interaksi ( perkalian variabel perilaku mencari umpan balik dengan keadilan prosedural ) terhadap kinerja (b3) juga signifikan $(\beta=0,086$; 
Sig $=0,000<$ alpha 0,05). Dari keterangan di atas dapat disimpulkan bahwa variabel keadilan prosedural menjadi variabel moderasi dalam hubungan antara perilaku mencari umpan balik dengan kinerja sehingga $\mathrm{H} 2$ dapat diterima.

Tabel 2 . Hasil Uji Interaksi Keadilan Prosedural terhadap Kinerja

\begin{tabular}{|c|c|c|c|c|c|}
\hline Variabel & $\mathbf{n}$ & $R^{2}$ & $\boldsymbol{\beta}$ & $t$ & Sig. \\
\hline \multicolumn{6}{|l|}{ Step 1} \\
\hline Feedback Seeking Behavior & 235 & 0,288 & 0,504 & 9,697 & 0,000 \\
\hline \multicolumn{6}{|l|}{ Step 2} \\
\hline Feedback Seeking Behavior & 235 & 0,387 & 0,496 & 10,326 & 0,000 \\
\hline Procedural Justice & 235 & 0,393 & 0,290 & 6,335 & 0,000 \\
\hline \multicolumn{6}{|l|}{ Step 3} \\
\hline $\begin{array}{l}\text { Feedback Seeking Behavior x } \\
\text { Procedural Justice }\end{array}$ & 235 & 0,469 & 0,086 & 5,786 & 0,000 \\
\hline
\end{tabular}

Hasil pengujian menunjukkan bahwa keadilan prosedural memoderasi hubungan antara perilaku mencari umpan balik dengan kinerja. Individu menerima feedback atas kinerjanya maka dia akan menilai keadilan dari feedback tersebut, bagaimana feedback itu ditentukan dan bagaimana feedback tersebut dikomunikasikan kepada mereka. Feedback yang adil dapat lebih diterima dan dilaksanakan dibandingkan feedback yang kurang adil secara prosedural. Sehingga dapat disimpulkan perilaku mencari umpan balik akan meningkatkan kinerja tergantung dari persepsi adil tidaknya sebuah feedback. Semakin adil prosedur maka semakin kuat hubungan perilaku mencari umpan balik dengan kinerja maupuan kejelasan peran . Semakin tidak adil prosedur maka semakin lemah hubungan antara perilaku mencari umpan balik dengan kinerja. Individu mencari umpan balik dalam rangka mencapai standar kinerja yang diharapkan atasan. Semakin tinggi persepsi keadilan prosedural , maka umpan balik dari proses pencarian membuat semakin memperjelas standar kinerja yang diharapkan oleh atasan sehingga bawahan memahami apakah kinerja yang dicapainya sudah sesuai dengan keinginan atasan atau belum. Sebaliknya semakin rendah persepsi keadilan prosedural, maka umpan balik dari proses pencarian menjadi kurang bermanfaat untuk memahami standar kinerja yang diharapkan oleh atasan sehingga pencapaian kinerja seperti harapan atasan akan sulit untuk dipenuhi.

Hasil penelitian ini sejalan dengan tiga penelitian sebelumnya yang berhubungan (Bos et al.,1998; Nae et al., 2015; Li et al., 2016). Ketika supervisor menggunakan menggunakan prosedur yang adil dalam membuat keputusan , karyawan akan lebih menerima keputusan tersebut dan keputusan tersebut dirasakan lebih positif. Sebaliknya ketika supervisor menggunakan prosedur yang tidak adil dalam membuat keputusan, karyawan akan sulit menerima keputusan tersebut dan keputusan tersebut dirasakan negatif. Partisipasi bawahan dalam membuat keputusan dapat menstimulasi dan mendorong perilaku bawahan dalam mencari umpan balik. Kesempatan pastisipasi bawahan selama pengambilan keputusan ada di dalam sebuah organisasi dimana terdapat keadilan prosedural.

\section{KESIMPULAN}

Umpan balik sebagai hasil dari proses pencarian terbukti dapat membantu bawahan dalam mengurangi kesenjangan kinerja antara kinerja aktual bawahan dengan standar kinerja yang diinginkan atasan. Meningkatnya jumlah umpan balik sebagai efek meningkatnya intensitas 
pencarian membuat rasa kontrol bawahan menjadi semakin kuat terhadap setiap tahap pekerjaan. Adanya kesalahan atau kekurangan dalam pekerjaan dapat segera diketahui untuk dilakukan perbaikan sehingga karyawan dapat bekerja secara lebih efektif dan efisien.

Keadilan prosedural juga terbukti memoderasi hubungan antara perilaku mencari umpan balik dengan kejelasan peran maupun kinerja. Adanya keadilan prosedural dalam pemberian umpan balik dapat memperkuat hubungan positif perilaku mencari umpan balik terhadap kejelasan peran. Umpan balik yang lahir dari adanya keadilan prosedural akan mempermudah bawahan dalam memahami tujuan, standar evaluasi, dan prosedur dalam pekerjaan yang pada gilirannya akan meningkatkan kinerja bawahan.

Penelitian ini diharapkan dapat memberikan jawaban atas hasil penelitian sebelumnya yang masih kontradiktif. Pemilihan metode dan sumber umpan balik dalam perilaku mencari umpan balik ternyata berpengaruh terhadap hasil penelitian. Metode inquiry pada perilaku mencari umpan balik dengan sumber umpan balik adalah atasan langsung menghasilkan hubungan yang signifikan antara perilaku umpan balik dengan kinerja maupun terhadap kejelasan peran. Penelitian ini juga memberikan kontribusi dimana keadilan prosedural berpengaruh terhadap hubungan antara perilaku mencari umpan balik dengan kinerja. Keadilan prosedural terbukti memoderasi hubungan tersebut.

Hasil penelitian mempunyai manfaat aplikatif baik bagi bawahan ,atasan, dan organisasi. Bagi bawahan perilaku mencari umpan balik sangat penting dilakukan dalam rangka peningkatan kinerja maupun kejelasan peran. Meningkatnya frekuensi meminta umpan balik kepada atasan terbukti dapat mengurangi gap kinerja. Semakin tinggi frekuensi pencarian semakin banyak informasi bermanfaat yang diperoleh dalam rangka memperjelas tujuan pekerjaan, standar evaluasi dan prosedur dalam mencapai tujuan tersebut. Sehingga bawahan dalam bekerja dapat lebih efektif dan efisien.

Bagi atasan, menegakkan keadilan prosedural dalam proses pemberian umpan balik menjadi sangat penting karena bawahan akan menilai setiap umpan balik yang diberikan. Bawahan dalam menerima umpan balik atas kinerjanya maka dia akan menilai keadilan dari umpan balik tersebut, bagaimana umpan balik itu ditentukan dan bagaimana umpan balik tersebut dikomunikasikan kepada mereka. Umpan balik yang adil dapat lebih diterima dan dilaksanakan dibandingkan umpan balik yang kurang adil secara prosedural.

Bagi organisasi, ketika sumber umpan balik adalah atasan maka harus dipastikan atasan harus mempunyai kompetensi yang cukup dalam bidang tersebut.. metode pengisian jabatan tidak lagi berdasarkan urutan kepangkatan tetapi lebih mengedepankan aspek kompetensi dan pengalaman. Hal ini sangat penting untuk menjamin bahwa atasan mengetahui tujuan, prosedur dan standar evaluasi setiap pekerjaan bawahannya sehingga ketika bawahan meminta umpan balik dapat memberikan umpan balik yang bermanfaat dan memenuhi unsur keadilan secara prosedural.

Penelitian ini masih mempunyai kekurangan. Masih diperlukan kajian secara lebih mendalam lagi bagaimana umpan balik dapat meningkatkan kinerja. Penjelasan tentang bagaimana proses penerimaan umpan balik sampai dengan umpan balik tersebut mempengaruhi dan memotivasi bawahan untuk meningkatkan kinerja sehingga nantinya dapat dihasilkan gambaran yang jelas model yang lebih komprehensif.

Penelitian Ilgen et al (1979) menggambarkan model teoritis dari proses umpan balik ada 4 tahap, yaitu tahap merasakan umpan balik, tahap memutuskan menerima karena umpan balik dirasakan akurat, tahap dimana individu yakin bahwa umpan balik tersebut berguna , dan tahap dimana penerima umpan balik benar-benar melaksanakan umpan balik tersebut. Hasil penelitian sebelumnya secara empiris menunjukkan bahwa umpan balik 
mengarah kepada peningkatan dan pengembangan karyawan ketika karyawan merasakan umpan balik yang mereka terima akurat dan berguna (Kinicki, et.al , 2004). Penelitian selanjutnya disarankan untuk memasukkan variabel perceived feedback accurate dan variabel perceived feedback useful dalam memperjelas hubungan perilaku mencari umpan balik terhadap peningkatan kinerja.

\section{DAFTAR PUSTAKA}

Ang, S., Cummings, L., Straub, D., \& Early, P. (1993). The effects of information technology and the perceived mood of the feedback giver on feedback seeking. Information Systems Research, 4, 240-261.

Anseel, F., Lievens, F., \& Schollaert, e. (2009). Reflection as a strategy to enhance task performance after feedback. Organizational Behavior and Human Decision Processes, 110: 23-35.

Anseel, F., Betty, Shen Lievens, F., \& Sackett, (2015). How Are We Doing After 30 Years? A MetaAnalytic Review of the Antecedents and Outcomes of Feedback-Seeking Behavior. Journal of Management Vol. 41 No. 1, January 2015 318-348

Aragon-Correa, J. A. 1998. Strategic proactivity and form approach to the natural environment. Academy of Management Journal, 41: 55-567.

Ashford,S.(1986). Feedback seeking in individual adaptation : A resource perspective. Academy of Management Journal, 29, 465-487.

Ashford, S. J., \& Cummings, L. L. 1983. Feedback as an individual resource: Personal strategies of creating information. Organizational Behavior and Human Performance, 32: 370-398

Ashford, S., \& Black, J. (1996). Proactivity during organizational entry: The role of desire for control. Journal of Applied Psychology, 81, 199-214.

Ashford, S., Blatt, R., \& VandeWalle, D. (2003). Reflections on the looking glass: A review of research on feedback seeking behavior in organizations. Journal of Management, 29, 773-799.

Ashford, S. J., \& Tsui, A. S. (1991). Self-regulation for managerial effectiveness: The role of active feedback-seeking. Academy of Management Journal, 34, 251-280.

Borman, W. C., \& Motowidlo, S. J. 1993. Expanding the criterion domain to include elements of contextual performance. In N. Schmitt, W. C. Borman, and associates (Eds.), Personnel selection in organizations: 71-98. San Francisco: Jossey-Bass

Brett, J. F., \& Atwater, L. E. (2001). 360-degree feedback: Accuracy, reactions, and perceptions of usefulness. Journal of Applied Psychology, 86, 930-942.

Brown, S. P., Ganesan, S., \& Challagalla, G. (2001). Self-efficacy as a moderator of informationseeking effectiveness. Journal of Applied Psychology, 86, 1043-1051.

Chatman, J. A., \& Cha, S. E. (2003). Leading by Leveraging Culture. California Management Review, 45(4), 20-34.

Chen ,Z.,Lam,W.,\& Zhong,J.A.(2007).Leader-member exchange and member performance : A new look at individual level negative feedback-seeking behavior and team-level empowerment climate. Journal of Applied Psychology, 92(1), 202-212.

Colquitt, J. A. (2001). On the dimensionality of organizational justice: A construct validation of a measure. Journal of Applied Psychology, 86, 386-400. 
Chory, R. M., \& Kingsley Westerman, C. Y. (2009). Feedback and Fairness: The Relationship Between Negative Performance Feedback and Organizational Justice. Western Journal of Communication, 73(2), 157-181.

Cropanzano, R., \& Schminke, M. (2001). Using social justice to build effective work groups. In M. Turner (Ed.), Groups at work: Advances in theory and research (pp. 143-171). Hillsdale, NJ: Erlbaum.

De Stobbeleir K, Ashford S, Buyens D.2011.Self-regulation of creativity at work : the role of feedback-seeking behavior in creative performance. Academic Management. Journal. 54(4):811-31

Dweck, C. S. (1986). Motivational processes affecting learning. American Psychologist, 41, 10401048.

Dweck,C.S.(1999).Self-theories: Their role in motivation, personality, and development .Philadelphia : ThePsychology Press.

Dweck, C. S., \& Leggett, E. L. (1988). A social-cognitive approach to motivation and personality. Psychological Review, 95, 256-273.

Elliot, A. J., \& Church, M. A. (1997). A hierarchical model of approach and avoidance achievement motivation. Journal of Personality and Social Psychology, 72, 218-232

Eun Young Nae, Hyoung Koo Moon, Byoung Kwon Choi, (2015) "Seeking feedback but unable to improve work performance? Qualified feedback from trusted supervisors matters", Career Development International, Vol. 20 Issue: 1, pp.81-100,

Fedor, D.B., Rensvold R.B., \& Adams, S.M. (1992). An investigation of factors expected to affect feedback seeking: A longitudinal field study. Personal Psychology, 45, 779-805.

Ferris, G. R. (1985). Role of leadership in the employee withdrawal process: A constructive replication. Journal of Applied Psychology, 70, 777-781.

Folger, R., \& Konovsky, M. A. (1989). Effects of procedural and distributive justice on reactions to pay raise decisions. Academy of Management Journal, 32, 115-130.

Gregory, J. B., Levy, P. E., \& Jeffers, M. (2008). Development of a model of the feedback process within executive coaching. Consulting Psychology Journal: Practice and Research, 60, 4256.

Griffin, M. A., Neal, A., \& Parker, S. K. (2007). A new model of work role performance: Positive behavior in uncertain and interdependent contexts. Academy of Management Journal, 50, 327-347

Ilgen, D. R., Fisher, C. D., \& Taylor, M. S. 1979. Consequences of individual feedback on behavior in organizations. Journal of Applied Psychology, 64: 349-371.

Ilgen, D. R., \& Hollenbeck, J. R. 1991. The structure of work: Job design and roles.In M.D.Dunnette \& L.M. Hough (Eds.), Handbook of industrial and organisational psychology (2nd ed.): 165-207. Palo Alto, CA: Consulting Psychology Press.

Ilgen, D. R., \& Pulakos, E. D. 1999. Employee performance in today's organizations. In D. R. Ilgen \& E. D. Pulakos (Eds.), The changing nature of performance: Implications for staffing, motivation, an development: 21-55. San Francisco: Jossey-Bass.

Jackson, S. E., \& Schuler, R. S. 1995. Understanding human resource management in the context of organizations and their environments. In J. T. Spence, J. M. Darley, \& J. Foss (Eds.) Annual review of psychology, vol. 46: 237-264. Palo Alto, CA: Annual Reviews.

Jawahar, I.M. (2006) Correlates of Satisfaction with Performance Appraisal Feedback. Journal of Labor Research, 27, 213-236. 
Kim T,Cable DM, Kim S, Wang J.2009. Emotional competence and work performance : the mediating effect of proactivity and the moderating effect of job autonomy. J. Organ. Behav. 30(7):983-1000

Kluger, A., \& DeNisi, A. (1996). Effects of feedback intervention on performance: A historical review, a meta-analysis, and a preliminary feedback intervention theory. Psychological Bulletin, 119, 254-284.

Korman, A. K. (2001). Self-enhancement and self-protection: Towards a theory of motivation. In M. Erez, U. Kleinbeck, \& H. Thierry (Eds.), Work motivation in the context of globalizing economy (pp. 121-130).

Lam, W., Huang, X., \& Snape, E. (2007). Feedback seeking behavior and leader Member exchange: Do supervisor attributions matter? Academy of Management Journal, 50, 348-363.

Levy, P., Albright, M., Cawley, B., \& Williams, J. (1995). Situational and individual determinants of feedback seeking: A closer look at the process. Organizational Behavior \& Human Decision Processes, 62, 23-34.

Leventhal, G. S. (1980). What should be done with equity theory? New approaches to the study of fairness in social relationships. In K. Gergen, M. Greenberg, \& R. Willis (Eds.), Social exchange: Advances in theory and research (pp. 27-55). New York: Plenum Press.

Locke, E A (1968) Toward a theory of task motivation and incentives Organizational Behavior and Human Performance. 3. 157-189

London, M. (2003). Job feedback: Giving, seeking and using feedback for performance improvement (2nd ed.). Mahwah, NJ: Erlbaum.

London, M., \& Maurer, T. J. (2004). Leadership development: A diagnostic model for continuous learning in dynamic organizations. In J. Antonakis, A. T. Cianciolo, \& R. J. Sternberg (Eds.), The nature of leadership (pp. 222-246). Thousand Oaks, CA: Sage.

London, M., \& Smither, J. M. (2002). Feedback orientation, feedback culture, and the longitudinal performance management process. Human Resource Management Review, 12, 81-100.

McFarlin, D. B., \& Sweeney, P. D. (1992). Distributive and procedural justice as predictors of satisfaction with personal and organizational outcomes. Academy of Management Journal, 35, 626-637.

Morrison, E. (1993). Longitudinal study of the effects of information seeking on newcomer socialization. Journal of Applied Psychology, 78, 173-183.

Morrison,E.W.,\& Vancouve r,J.B.(2000) .Within person analysis of information seeking: The effects of perceived costs and benefits. Journal of Management, 26, 119-137.

Mukherjee, A. and Malhotra, N. (2006), "Does role clarity explain employee-perceived service quality?: A study of antecedents and consequences in call centres",International Journal of Service Industry Management, Vol. 17 No. 5, pp. 444-473.

Northcraft, G.B., \& Ashford, S.J. (1990). The preservation of self in everyday life: The effects of performance expectations and feedback context on feedback inquiry. Organizational Behavior and Human Decision Processes, 47, 42-64.

Podsakoff,P.M.,MacKenzie,S.B.,Lee,J.Y.,\&Podsakoff,N.P.(2003).Common method biases in behavioral research : A critical review of the literature and recommended remedies. Journal of Applied Psychology, 88, 879-903.

Podsakoff,P.M.,\& MacKenzie, S.B.(2005).Organizational citizenship behavior: Its nature, antecedents, and consequences. Thousand Oaks, CA: Sage.

Podsakoff, P., MacKenzie, S., Paine, J., \& Bachrach, D. (2000). Organizational citizenship behaviors: A critical review of the theoretical and empirical literature and suggestions for future research. Journal of Management, 26, 513-563. 
Porath, C. L, \& Bateman, T. (2006). Self-regulation: From goal orientation to job performance. Journal of Applied Psychology, 91, 185-192.

Regina H. Mulder, (2013) "Exploring feedback incidents, their characteristics and the informal learning activities that emanate from them", European Journal of Training and Development, Vol. 37 Issue: 1, pp.49-71

Regina H. Mulder \& Andrea D. Ellinger, (2013) "Perceptions of quality of feedback in organizations: Characteristics, determinants, outcomes of feedback, and possibilities for improvement: introduction to a special issue", European Journal of Training and Development, Vol. 37 Issue: 1, pp.4-23,

Renn, R. W., \& Fedor, D. B. (2001). Development and field test of a feedback seeking, self-efficacy, and goal setting model of work performance. Journal of Management, 27, 563-583.

Sharma, D., \& Marandure, D. (2011). Creating Value Through the Strategic Use of Feedback. SSRN Electronic Journal.

Sessa, V. I., \& London, M. (2006). Continuous learning in organizations. Mahwah, NJ: Erlbaum.

Thibaut, ]., \& Walker, L. (1975). Procedural justice: A psychological analysis. Hillsdale, NJ: Erlbaum.

Tuckey, M., Brewer, N., \& Williamson, P. (2002). The influence of motives and goal orientation on feedback seeking. Journal of Occupational \& Organizational Psychology, 75, 195-216.

VandeWalle, D. (1997). Development and validation of a work domain goal orientation instrument. Educational and Psychological Measurement, 57, 995-1015.

VandeWalle, D. (2003). A goal orientation model of feedback-seeking behavior. Human Resource Management Review, 13, 581-604.

VandeWalle, D., \& Cummings, L. (1997). A test of the influence of goal orientation on the feedback seeking process. Journal of Applied Psychology, 82, 390-400.

VandeWalle, D., Ganesan, S., Challagalla, G., \& Brown, S. (2000). An integrated model of feedbackseeking behavior: Disposition, context, and cognition. Journal of Applied Psychology, 85, 996-1003.

Van Knippenberg, D, De Dreu, C. K. W., \& Homan, A. C. (2004). Work group diversity and group performance: An integrative model and research agenda. Journal of Applied Psychology, 98, 1008-1022.

Wanberg,C.,\&Kammeyer-Mueller,J.(2000). Predictors and outcomes of proactivity in the socialization process. Journal of Applied Psychology, 85, 373-385.

Whitaker , B, Levy P.(2012). Linking feedback quality and goal orientation to feedback seeking and job performance. Human Performance. 25:159-78

Williams, J., \& Johnson, M. (2000). Self-supervisor agreement: The influence of feedback seeking on the relationship between self and supervisor ratings of performance. Journal of Applied Social Psychology, 30, 275-292.

Zhou, J. 2008. Promoting creativity through feedback. In J. Zhou \& C. E. Shalley (Eds.), Handbook of organizational creativity: 125-145. New York: Erlbaum 